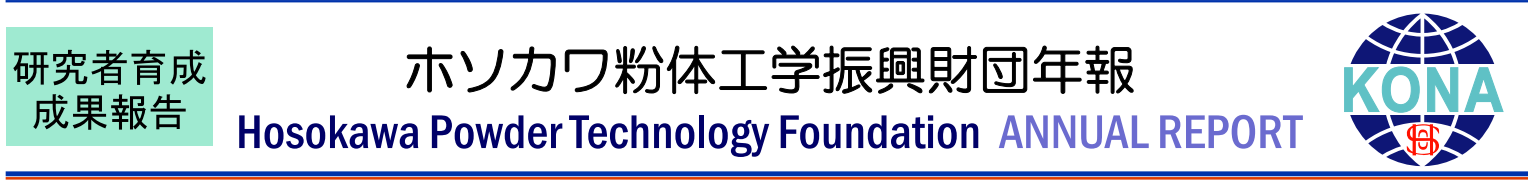

\section{マイクロ波加熱式熱重量測定装置の開発と 機能性粒子合成への利用 \\ Development of Microwave Heating Thermogravimetry Apparatus and Its Application to Synthesis of Functional Powder}

援助対象者 Scholarship Student: Achmad Dwitama KARISMA

広島大学大学院工学研究科化学工学専攻 博士課程後期 3 年

Graduate School of Engineering, Hiroshima University, PhD Student (D3)

E-mail: ach.dwitama@gmail.com

研究指導者 Academic Leader：福井 国博 Kunihiro FUKUI

教授, Professor

E-mail: kfukui@hiroshima.-u.ac.jp

抄 録

シングルモード型マイクロ波加熱熱重量測定装置を新規に開発し, 種々の条件に扔ける $\mathrm{CuO}$ のマ イクロ波吸収効率および誘電率損失の温度依存性が文献デー夕と良好に一致していることを示すこ とで，その信頼性・有効性を明らかにした。また，マイクロ波加熱直接脱硝反応（MDD）法によ る $\mathrm{NiCuZn}$ フェライトナノ粒子の合成法を検討し, 磁気特性の優れた $\mathrm{Ni}_{0.5} \mathrm{Cu}_{0.1} \mathrm{Zn}_{0.4} \mathrm{Fe}_{2} \mathrm{O}_{3}$ が金属硝 酸塩水和物溶液の混合物から合成できることを初めて明らかにした。

\begin{abstract}
The microwave heating mechanism of $\mathrm{CuO}$ was investigated by the newly developed single mode type of microwave thermogravimetric (MWTG) apparatus. The result shows that the microwave absorption efficiency and the permittivity loss of $\mathrm{CuO}$ in various temperature conditions are in good agreement with the literature data. It clarified the reliability and effectiveness of the MWTG apparatus. Moreover, the synthesis of NiCuZn ferrite nanoparticles by microwave direct denitration (MDD) method also was examined. The $\mathrm{Ni}_{0.5} \mathrm{Ca}_{0.1} \mathrm{Zn}_{0.4} \mathrm{Fe}_{2} \mathrm{O}_{3}$ with excellent magnetic properties can be synthesized from the mixture of metal nitrate hydrate solutions was revealed.
\end{abstract}

\section{成 果 の 概 要}

Microwave heating has long been used for diverse purposes, such as food processing, drying, coal treatment, synthesis of organic and inorganic materials, and so on. Microwave heating enables the 
direct, rapid, and selective heating of a material with higher efficiency compared with conventional heating. Therefore, microwave heating is a promising method to synthesize the important material, such as ceramics and catalysts, that involves the chemical reactions. However, the mechanism of the chemical reaction during the microwave heating process has not been explained sufficiently. To clarify this issue, it is necessary to investigate the reaction temperature, the microwave energy absorbed by the material, and the change in the mass of material, simultaneously in situ during the progress of reaction that involves microwave heating. Therefore, a microwave heating thermogravimetry (MWTG) apparatus should thus be developed to enable the measurement of these parameters. Moreover, the application of the microwave heating method on material synthesis, such as NiCuZn ferrite, and CuCeZr oxide nanoparticles were also investigated.

The mechanism of the microwave heating process throughout the development of the single-mode type microwave heating thermogravimetry (MWTG) apparatus was investigated. Fig. 1 shows the schematic diagram of a developed MWTG apparatus.

The temperature distribution, microwave absorption efficiency, and permittivity loss of copper oxide $(\mathrm{CuO})$ pellet heated by microwave irradiation were investigated to clarify the validation of the developed single-mode type MWTG apparatus. The result shows that the temperature distribution and microwave absorption efficiencies on various temperature reaction of the $\mathrm{CuO}$ determined by numerical simulation could be validated by MWTG apparatus. Moreover, the temperature dependence of the estimated permittivity loss of the $\mathrm{CuO}$ agrees well with the previously published results (Samouhos M. et al., 2011) as shown in Fig. 2. In addition, the mass measurement of the $\mathrm{CuO}$ sample during the microwave heating process measured by MWTG apparatus have a good agreement with TG-DTA measurement.

The application of the microwave heating method to material synthesis was also investigated. $\mathrm{Ni}_{0.5} \mathrm{Cu}_{0.1} \mathrm{Zn}_{0.4} \mathrm{Fe}_{2} \mathrm{O}_{4}$ were synthesized from a mixture of metal nitrate hydrate solutions. As a

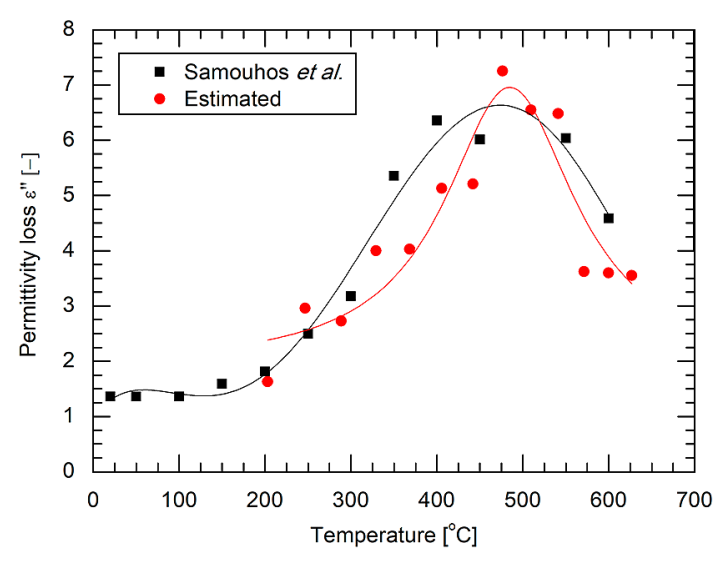

Fig. 2 Comparison of previously published and presently estimated permittivity losses of $\mathrm{CuO}$.

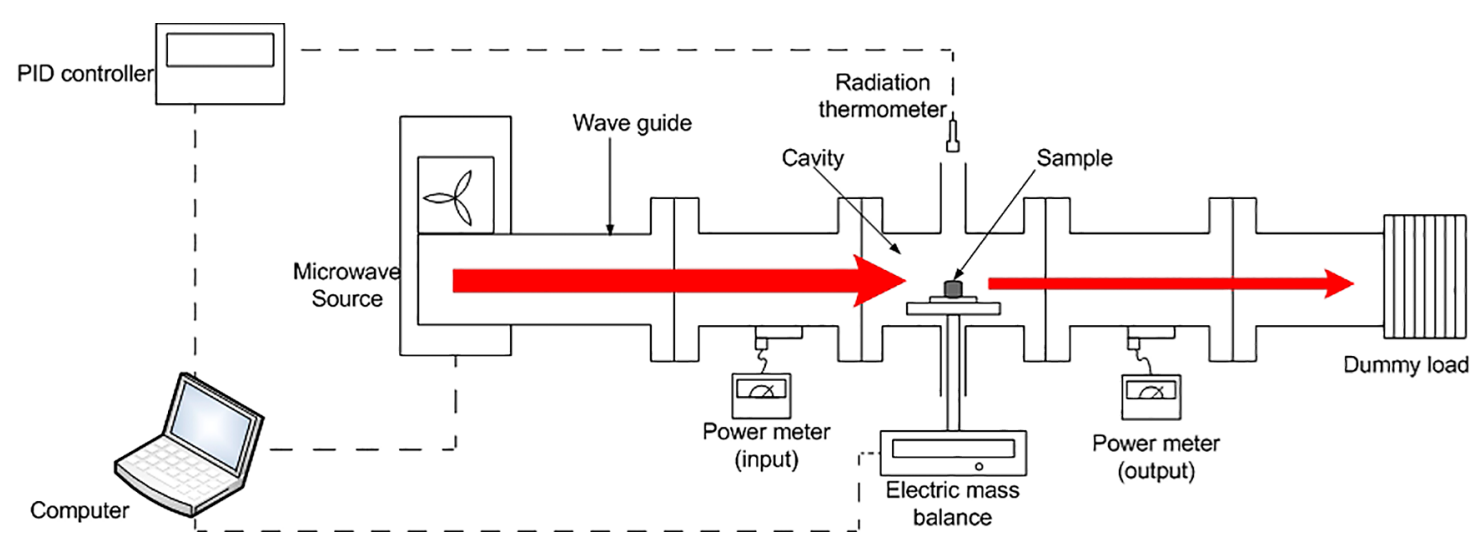

Fig. 1 Schematic diagram of developed single-mode-type microwave heating thermogravimetry apparatus. 
comparison, NiCuZn ferrite was also synthesized from the mixture of metal oxide powder by solidstate reaction (SSR) method. The result shows that the microwave heating method could provide the single phase of NiCuZn ferrite powder with an average particle diameter of about $30 \mathrm{~nm}$ at a reaction temperature of $900^{\circ} \mathrm{C}$. The particle diameter was less than one-fifth of that by SSR method at the same reaction temperature. The saturation magnetization of product synthesized by microwave heating method was found $25.08 \mathrm{emu} / \mathrm{g}$, which was more than three times that by SSR method. On the other hand, the coercivity of the product synthesized by microwave heating method, 55.21 Oe was found about half of that obtained by the SSR method. This result suggests that the microwave heating method could provide more attractive soft ferrite magnetic characteristics of $\mathrm{NiCuZn}$ ferrite nanoparticle to the product powder.

The microwave heating method was also applied to the synthesis of $\mathrm{CuCeZr}$ oxide nanoparticles from the mixture of metal nitrate hydrate solutions. The $\mathrm{Ce}_{0.6} \mathrm{Zr}_{0.4} \mathrm{O}_{2}: \mathrm{Cu}(\mathrm{CCZ})$ nanoparticles were synthesized by microwave heating method and compared their properties with those by the citric acid method.

\section{外部発表成果}

\section{論文発表}

1. Karisma A.D., Hamaba T., Fukasawa T., Huang A.-N., Segawa T., Fukui K., Validation of measured microwave absorption and temperature change for development of a single-mode-type microwave heating thermogravimetry apparatus, Review of Scientific Instruments, 88 (2017) 024101. DOI: $10.1063 / 1.4974813$

2. Fukasawa T., Karisma A.D., Shibata D., Huang
As the result, the CCZ nanoparticles could be obtained below $20 \%$ of $\mathrm{Cu}$ doping ratio by both methods. The microwave heating method could provide the larger specific surface area of $\mathrm{CCZ}$ nanoparticles product than those by the citric acid method, i.e. $68.0 \mathrm{~m}^{2} / \mathrm{g}$ and $30 \mathrm{~m}^{2} / \mathrm{g}$, respectively. However, the CCZ nanoparticles synthesized by citric acid method had a little higher oxygen storage capacity (OSC) value than those by microwave heating method due to its crystallinity phase. Further, the ratio $\mathrm{Ce}^{3+} / \mathrm{Ce}$ content of $\mathrm{CCZ}$ nanoparticles synthesized by microwave denitration method is comparable to that by the citric acid method, i.e. $4.2 \%$ and $5.6 \%$, respectively. For the conclusion, the $\mathrm{CCZ}$ nanoparticles synthesized by microwave denitration method has a comparable microstructure and OSC value with shorter treatment time than that by citric acid method.

\section{参考文献}

Samouhos M., Hutcheon R., Paspaliaris I., Microwave reduction of copper (II) oxide and malachite concentrate, Minerals Engineering, 24 (2011) 903. DOI: 10.1016/ j.mineng.2011.03.026

A.-N., Fukui K., Synthesis of zeolite from coal fly ash by microwave hydrothermal treatment with pulverization process, Advanced Powder Technology, 28(3) (2017) 798-804. DOI: 10. 1016/j.apt.2016.12.006

3. Fukasawa T., Horigome A., Karisma A.D., Maeda N., Huang A.-N., Fukui K., Utilization of incineration fly ash from biomass power plants for zeolite synthesis from coal fly ash by microwave hydrothermal treatment, Advanced Powder Technology, 29(3) (2018) 450-456. DOI: 10. 1016/j.apt.2017.10.022 


\section{口頭・ポスター発表}

1. Karisma A.D., Shinokawa Y., Fukasawa T., Huang A., Fukui K., "NiCuZn-ferrite nanoparticle synthesis from metallic nitrate solution using microwave denitration method", The 7th Asian Particle Technology Symposium (Taoyuan, Taiwan, July 30-August 3, 2017) O2-1 65.
2. Karisma A.D., Nakamura R., Fukasawa T., Ishigami T., Fukui K., "Synthesis of Cu-Ce-Zr oxide catalyst nanoparticle by microwave denitration method", The 6th International Conference on the Characterization and Control of Interfaces for High Quality Advanced Materials (Kurashiki, Japan, July 9-12, 2018) P-A-09. 